\title{
Pengaruh Model Student Facilitator And Explaining (SFAE) Terhadap Kemampuan Berpikir Kritis
}

\author{
*Indah Mustikasari ${ }^{1}$, Supandi $^{2}$, Aries Tika Damayani ${ }^{3}$ \\ Pendidikan Guru Sekolah Dasar, Fakultas Ilmu Pendidikan, Universitas PGRI Semarang, Indonesia
}

\author{
A R T I C L E I N F O \\ Article history: \\ Received 10 May 2019 \\ Received in revised form \\ 10 June 2019 \\ Accepted 15 July 2019 \\ Available online 29 August \\ 2019 \\ Kata Kunci: \\ student facilitator and \\ explaining, kemampuan \\ berpikir kritis \\ Keywords: \\ student facilitator and \\ explaining, critical \\ thingking skills
}

\begin{abstract}
A B S T R A K
Berdasarkan hasil observasi, kemampuan berpikir kritis siswa masih kurang. Tujuan dari penelitian ini untuk mengetahui pengaruh model pembelajaran student facilitator and explaining (SFAE) terhadap kemampuan berpikir kritis pada siswa kelas $\mathrm{V}$. Peneliti menggunakan Pre-Eksperimental design yaitu One Group Pretest-Posttest Design. Peneliti menggunakan semua siswa kelas V di SD yaitu 30 siswa. Peneliti menggunakan tes tertulis sebagai intrumen penelitian. Data dihitung menggunakan uji-t juga didukung dengan uji N-Gain. Hasil penelitian menunjukkan bahwa model pembelajaran student facilitator and explaining berpengaruh terhadap kemampuan berpikir kritis pada siswa kelas V SD.
\end{abstract}

\begin{abstract}
A B S T R A C T
The purpose of this study was to determine the effect of the student facilitator and explaining learning model (SFAE) on critical thinking skills in fifth grade students of Elementary School. The researcher used the Pre-Experimental design, One Group Pretest-Posttest Design. The researcher used all fifth grade students at Lamper Tengah Elementary School 01 Semarang, which were 30 students. The researcher used a written test as a research instrument. Data was calculated using the t-test also supported by the N-Gain test. The results of the study showed that the student facilitator and explaining learning model influences critical thinking skills in fifth grade students of Lamper Tengah $S D$.
\end{abstract}

\section{Pendahuluan}

Pendidikan adalah usaha sadar dan terencana untuk mewujudkan suasana belajar dan proses pembelajaran agar peserta didik secara aktif mengembangkan potensi dirinya untuk memiliki kekuatan spiritual keagamaan, pengendalian diri, kepribadian, kecerdasan akhlak mulia, serta keterampilan yang diperlukan dirinya, masyarakat, bangsa, dan negara (Undang-Undang No. 20 tahun 2003 Pasal 1 tentang sistem pendidikan nasional). Ilmu Pengetahuan Alam (IPA) adalah salah satu mata pelajaran dalam KTSP yang merupakan suatu kumpulan pengetahuan yang tersusun secara sistematik dan dalam penggunaannya secara umum terbatas pada gejala-gejala alam dan perkembangannya tidak hanya ditandai oleh adanya kumpulan fakta, tetapi adanya metode ilmiah (Trianto, 2010:136). Diperkuat pendapat H.W Fowler (dalam Laksmi Prihantoro, 1986: 13) IPA adalah pengetahuan yang sistematis dan dirumuskan, yang berhubungan dengan gejala-gejala kebendaan dan didasarkan terutama atas pengamatan dan deduksi (Suja, 2015).

Pendidikan merupakan salah satu faktor yang sangat penting dalam perkembangan seorang individu baik dari sisi sikap, pengetahuan maupun keterampilan. Dalam proses perkembangan tersebut seorang individu akan mengalami suatu proses pembelajaran baik secara formal, informal maupun non formal. Proses pembelajaran yang dilakukan dalam lembaga formal tentu saja tidak akan lepas dari peran 
seorang guru (pendidik). Guru merupakan salah satu fasilitator dalam melaksanakan pembelajaran. Adapun tugas seorang guru adalah merencanakan, menilai dan mengevaluasi proses pembelajaran. Pendidikan adalah upaya untuk menciptakan sistem pembelajaran yang bertujuan untuk menumbuhkan pengetahuan tentang nilai, sikap dan perilaku sosial budaya yang memberikan banyak tantangan pada siswa. Pembelajaran merupakan proses timbal balik antar guru dan siswa dengan sumber dan lingkungan belajar. Berdasarkan Permendikbud No. 67 tahun 2013 tentang kurikulum SD menyatakan bahwa, pola pikir pembelajaran dikembangkan dari metode belajar yang memfokuskan guru menuju siswa, metode belajar satu arah ini bertujuan agar menuju pembelajaran yang interaktif, metode belajar sendiri menjadi kelompok, dan pola pemikiran faktual menuju kritis. Pada kenyataan, pembelajaran berpusat pada guru sehingga keaktifan siswa belum tumbuh.

Kegiatan belajar mengajar mengandung sejumlah komponen yang meliputi tujuan, bahan pelajaran, kegiatan belajar mengajar, metode, alat, dan sumber serta penilaian. Dari semua komponen tersebut metode mengajar merupakan salah satu komponen yang sangat penting dalam upaya pencapaian tujuan belajar. Karena pada hakikatnya proses belajar mengajar merupakan suatu upaya agar peserta didik mampu mengintegrasikan berbagai pengalaman sehingga dapat mencapai tujuan belajar yang diinginkan, dan diharapkan pula peserta didik mampu memahami materi yang disampaikan. Proses belajar mengajar bagi seorang peserta didik khususnya dalam pelajaran matematika dapat dilihat dari tingkat pemahaman dan penguasaan materi. Keberhasilan peserta didik dalam menguasai pelajaran matematika tersebut juga berkaitan erat dengan pemahaman konsep dalam materi matematika. Rendahnya hasil belajar matematika disebabkan oleh beberapa faktor antara lain ditinjau dari tuntutan kurikulum yang lebih menekankan pada pencapaian target, bukan pemahaman peserta didik terhadap konsep-konsep matematika, serta aktivitas pembelajaran di kelas, yang mana guru aktif sementara siswa pasif. Akibatnya, anak cenderung menerima apa adanya, tidak memiliki sikap kritis (Eva, 2016).

Berpikir kritis adalah suatu kegiatan berpikir tentang gagasan yang berhubungan dengan konsep atau masalah yang dipaparkan Susanto (2013). Berpikir kritis memiliki peran dalam pembelajaran. Semakin tinggi kemampuan siswa dalam berpikir kritis maka semakin mudah bagi siswa untuk dapat mengikuti proses pembelajaran dengan sangat baik. Klasifikasi berpikir kritis menurut Ennis dibagi ke dalam dua bagian, yaitu aspek umum dan aspek yang berkaitan dengan materi pelajaran. Berikut indikator-indikator dari masing-masing aspek berpikir kritis yang berkaitan dengan materi pelajaran, yaitu; a) Memberikan penjelasan sederhana, yang meliputi memfokuskan pertanyaan, menganalisis pertanyaan, bertanya dan menjawab tentang suatu penjelasan atau tantangan. b) Membangun keterampilan dasar yang meliputi, mempertimbangkan apakah sumber dapat dipercaya, mengamati dan mempertimbangkan suatu laporan hasil observasi. c) Menyimpulkan yang meliputi, mendeduksi dan mempertimbangkan hasil deduksi, menginduksi dan mempertimbangkan hasil induksi, dan membuat dan menentukan nilai pertimbangan. d) Memberikan penjelasan lanjut yang meliputi, mendefinisikan istilah dan petimbangan definisi dalam tiga dimensi, berinteraksi dengan orang lain. e) Mengatur strategi dan taktik yang meliputi, menentukan tindakan, dan berinteraksi dengan orang lain. Untuk mengembangkan strategi pada siswa dalam kemampuan berpikir kritis agar optimal, salah satunya dengan cara menggunakan model pembelajaran SFAE.

Model pembelajaran yang dipilih harus mampu membangkitkan motivasi atau gairah baik bagi peserta didik maupun bagi guru dalam proses pembelajaran sehingga dapat mencapai tujuan pembelajaran yang diinginkan dan memaksimalkan hasil belajar siswa. Terdapat banyak model pembelajaran yang dapat digunakan dalam pembelajaran matematika. Salah satunya yaitu model Student Facilitator and Explaining (SFE) dengan model konvensional. Guru adalah suatu sebutan bagi jabatan, posisi, dan profesi bagi seseorang yang mengabdikan dirinya dalam bidang pendidikan melalui interaksi edukatif secara terpola, formal, dan sistematis. Dalam UU R.I. Nomor 14 Tahun 2005 tentang guru dan dosen pada bab I pasal 1 dinyatakan bahwa: Guru adalah pendidik profesional dengan tugas utama mendidik, mengajar, membimbing, mengarahkan, melatih, menilai, dan mengevaluasi peserta didik pada pendidikan anak usia dini jalur pendidikan formal, pendidikan dasar, dan pendidikan menengah. (Sinar Grafika, 2011).

Guru yang profesional akan tercermin dalam penampilan pelaksanaan pengabdian tugas-tugas yang ditandai dengan keahlian, baik dalam materi maupun metode. Di samping keahliannya, sosok guru profesional ditunjukkan melalui tanggung jawabnya dalam melaksanakan seluruh pengabdiannya. Guru profesional hendaknya mampu memikul dan melaksanakan tanggung jawabnya sebagai guru kepada peserta didik, orang tua, masyarakat, bangsa, negara, dan agamanya. Sebagai pengajar atau pendidik, guru merupakan salah satu faktor penentu keberhasilan setiap upaya pendidikan. Itulah sebabnya setiap adanya inovasi pendidikan, khususnya dalam kurikulum dan peningkatan sumber daya manusia yang dihasilkan dari upaya pendidikan, selalu bermuara pada faktor guru. Hal ini menunjukkan bahwa betapa eksisnya peran guru dalam dunia pendidikan. Guru menjadi faktor yang menentukan mutu pendidikan 
karena guru berhadapan langsung dengan para peserta didik dalam proses pembelajaran di kelas. Di tangan guru, mutu dan kepribadian peserta didik dibentuk. Karena itu, perlu sosok guru kompeten, bertanggung jawab, terampil, dan berdedikasi tinggi. Guru adalah kurikulum berjalan. Sebaik apa kurikulum dan sistem pendidikan yang ada tanpa didukung oleh kemampuan guru, semuanya akan siasia. Guru berkompeten dan bertanggung jawab, utamanya dalam mengawal perkembangan peserta didik sampai ke suatu titik maksimal. Tujuan akhir seluruh proses pendampingan guru adalah tumbuhnya pribadi dewasa yang utuh. Seiring dengan kemajuan teknologi informasi yang begitu pesat, guru tidak lagi sekedar bertindak sebagai penyaji informasi. Dengan demikian, guru juga harus senantiasa meningkatkan keahliannya dan senantiasa mengikuti perkembangan ilmu pengetahuan dan teknologi sehingga ia mampu menghadapi berbagai tantangan (Shabir, 2015).

Pembelajaran Student Facilitator and Explaining dapat memacu siswa untuk menggunakan kemampuan linguistik, diperlihatkan dalam bentuk kegiatan atau perilaku menggunakan bahasa dengan lancar, mampu mengekspresikan serta mengapresiasikan dan mengapersepsi kata-kata yang bermakna kompleks. Seseorang yang berkecerdasan linguistik mampu mengekspresikan semua idenya bisa melalui bentuk tulisan bahkan dalam berbicara. (Muchyidin \& Kartika, 2014; Susanto et al., 2014) Namun, belum ada penelitian sebelumnya yang menerapkan model pembelajaran Student Facilitator and Explaining terhadap hasil belajar dan ditinjau dari kecerdasan linguistic (Widyawati, 2016).

Menurut Huda, (2017) mengemukakan bahwa Model Student Facilitator And Explaining merupakan penyampaian materi bahan ajar diawali dengan penjelasan umum, memberikan kesempatan siswa menjelaskan kembali pada teman-temannya, diakhiri penyampaian materi pada siswa. Dengan demikian model pembelajaran Student Facilitator And Explaining diharapkan dapat berpusat pada potensi, karakter siswa, perkembangan, pemahaman konsep dan kemampuan berpikir kritis terhadap perkembangan ilmu pengetahuan, teknologi, seni dan belajar sepanjang hayat.

Hasil wawancara yang peneliti lakukan pada tanggal 10 Oktober 2018 dengan Ibu Zuani Rahmi, S.Pd selaku guru kelas V SD N Lamper Tengah 01 Semarang menyatakan bahwa dalam pembelajaran tematik, banyak siswa yang mendapati kesulitan dalam belajar. Dari 30 siswa kelas V, 19 siswa atau 63,4\% diantaranya masih mendapatkan nilai kurang dari KKM, sedangkan 11 siswa atau 36,6 \% sudah mencapai KKM. Terlihat dari pembelajaran tematik tema sebelumnya sebagian hasil belajar siswa belum mencapai kriteria ketuntasan minimal (KKM) yaitu 72.

Penggunaam model yang dilakukan oleh guru seperti Inkuiri atau Tutor sebaya tetapi belum terbiasa menilai berpikir kritis dan memecahkan masalah. Model pembelajaran yang disampaikan oleh guru hanya berdasarkan materi dan gambar yang terdapat dibuku siswa dan masih menggunakan soal yang belum membuat siswa untuk berpikir kritis. Sehingga siswa masih belum berpengalaman untuk dapat menyelesaikan masalah. Dengan demikian hal ini mengakibatkan nilai rata-rata kelas $\mathrm{V}$ masih rendah. Berdasarkan masalah yang sudah dipaparkan diatas, peneliti melakukan tindakan alternatif pada siswa kelas V SD N Lamper Tengah 01 Semarang dengan pembelajaran yang aktif dan kreatif sehingga proses pembelajaran mempermudah siswa dalam pemahaman konsep dan penyelesaian masalah dengan cara berpikir kritis menggunakan model pembelajaran Student Facilitator And Explaining.

\section{Metode}

Penelitian ini menggunakan metode penelitian kuantitatif. Menurut Sugiyono (2017) penelitian kuantitatif disebut metode positivistik karena berlandaskan filsafat positivisme. Desain penelitian yang digunakan peneliti adalah Pre-Experimental Desaign. Peneliti menggunakan Pre-Experimental Desaign berupa One-Group Pretest-Posttest Desaign. Subjek penelitian ini semua siswa kelas V SDN Lamper Tengah 01 Semarang dengan jumlah 30 siswa. Pelaksanaan penelitian ini pada semester genap tahun pelajaran 2018/2019.

Teknik untuk pengumpulan data penelitian ini meliputi wawancara, tes, dan dokumentasi. Wawancara dilakukan dalam rangka untuk memperoleh data awal penelitian mengenai kegiatan belajar mengajar di kelas V SDN Lamper Tengah 01 Semarang. Observasi dilakukan peneliti dengan mengamati kegiatan pembelajaran yang dilakukan guru di kelas untuk mendapatkan data hasil belajar dan keadaan siswa saat pembelajaran. Tes digunakan peneliti untuk mengetahui kondisi siswa dengan menggunakan pretest-posttest soal yang berbentuk uraian. Pretest digunakan peneliti untuk megetahui kondisi awal siswa, dan posttest digunakan pada akhir pembelajaran setelah diberi perlakuan untuk mengetahui berhasil atau tidak pembelajaran. Pada penelitian ini, dokumentasi digunakan untuk keperluan peneliti mendapatkan data. Data-data yang diperoleh berupa daftar nama siswa, nilai ulangan harian, nilai ulangan tengah semester dan foto selama proses pembelajaran di kelas V SDN Lamper Tengah 01 Semarang sebagai dokumen atau bukti untuk menunjang penelitian. 
Teknik analisis data yang digunakan pada penelitian ini melalui beberapa tahapan, diantaranya; (1) Uji normalitas awal (pretest) bertujuan untuk menguji apakah nilai pretest siswa berasal dari populasi berdistribusi normal atau tidak. (2) Uji normalitas akhir (posttest) bertujuan menguji apakah nilai posttest siswa berasal dari populasi berdistribusi normal atau tidak. (3) Uji-t untuk mengetahui perbedaan nilai pretest siswa dengan nilai posttest siswa. (4) Uji N-Gain bertujuan mengetahui peningkatan pada hasil belajar siswa.

\section{Hasil dan Pembahasan}

Pada Penelitian dilaksanakan di kelas V SDN Lamper Tengah 01 Semarang dengan jumlah 30 siswa. Sebelum melakukan penelitian di SDN Lamper Tengah, dilakukan tes uji coba soal instrumen terlebih dahulu di kelas V SDN Mangunharjo. Dari uji coba yang dilakukan peneliti dan dihitung validitas, reliabilitas, daya beda serta taraf kesukaran, dihasilkan 14 dari 20 soal yang memenuhi syarat. Dari 14 soal tersebut hanya dipilih 10 soal yang dijadikan instrumen penelitian, kemudian dibuat soal pretestposttest. Pemberian pretest-posttest digunakan untuk mengetahui adakah pengaruh dari model student facilitator and explaining terhadap kemampuan berpikir kritis siswa kelas V SDN Lamper Tengah 01 Semarang. Perhitungan dari nilai pretest dan posttest setelah diberikan perlakuan mendapatkan hasil yang berbeda.

Tabel 1. Nilai Pretest dan Posttest Siswa Kelas V SDN Lamper Tengah 01 Semarang

\begin{tabular}{lll}
\hline Keterangan & Pretest & Posttest \\
\hline Nilai Terendah & 45 & 87,5 \\
Nilai Tertinggi & 57,5 & 100 \\
Rata-rata & 65,6 & 81,8 \\
Jumlah Siswa Tuntas & 6 & 26 \\
Jumlah Siswa Tidak Tuntas & 24 & 4 \\
\hline
\end{tabular}

Berdasarkan tabel 1, data sebelum diberikan perlakuan nilai pretest menunjukkan rata-rata 65,6 terdapat 24 siswa tidak tuntas serta 6 siswa yang tuntas. Hasil sesudah diberikan perlakuan nilai posttest menunjukkan rata-rata 81,8 terdapat 3 siswa yang tidak tuntas serta 17 siswa yang tuntas. Hasil dari nilai pretest dan posttest ini menunjukkan ada peningkatan kemampuan berpikir kritis siswa setelah diberi perlakuan.

Setelah memperoleh data hasil nilai pretest - posttest kemudian dilakukan analisis data awal dengan melakukan uji normalitas data. Penggunaan Uji normalitas untuk mengetahui data yang dianalisis akan berdistribusi normal atau tidak. Pada uji normalitas data yang diuji adalah data nilai pretest dan nilai posttest. Uji data ini menggunakan rumus liliefors yang diperoleh hasil perhitungan dari nilai prettest $\mathrm{L}_{0}=$ 0,096 dan $\mathrm{n}=30$ serta taraf signifikan 5\% didapat $\mathrm{L}_{\text {tabel }}=0,161$ dengan diperoleh $\mathrm{L}_{0}<\mathrm{L}_{\text {tabel }}$ atau $(0,096<0,161)$ maka $H_{a}$ diterima, artinya sampel berasal dari populasi yang berdistribusi normal. Berdasarkan data diperoleh hasil perhitungan dari nilai posttest $\mathrm{L}_{0}=0,077$ dan $=30$ dengan taraf signifikan 5\% didapat $\mathrm{L}_{\text {tabel }}=0,161$ dengan diperoleh $\mathrm{L}_{0}<\mathrm{L}_{\text {tabel }}$ atau $(0,077<0,161)$ maka $\mathrm{H}_{\mathrm{a}}$ diterima, artinya sampel berasal dari populasi yang berdistribusi normal.

Kemudian data yang diperoleh diolah menggunakan uji-t, pada perhitungan sebelumnya menunjukkan hasil nilai pretest-posttest berdistribusi normal. Setelah melakukan perhitungan, diperoleh hasil sebagai berikut:

Tabel 2. Analisis Uji t Kemampuan Berpikir Kritis Siswa Kelas V SDN Lamper Tengah 01 Semarang

\begin{tabular}{ccccc}
\hline d.b & Taraf Signifikansi & $\mathbf{t}_{\text {hitung }}$ & $\mathbf{t}_{\text {tabel }}$ & Keterangan \\
\hline 29 & $5 \%$ & 10,345 & 2,045 & $\mathrm{H}_{0}$ ditolak \\
\hline
\end{tabular}

Berdasarkan analisis data pada tabel 2, nilai pretest dan posttest dengan uji-t diperoleh thitung = $10,345 \mathrm{db}=\mathrm{N}-1=30-1=29$ dengan taraf signifikan 5\% sebesar 2,045 karena thitung $>t_{\text {tabel }}(10,345>2,045)$ menunjukkan bahwa uji t kemampuan berpikir kritis berpengaruh signifikan. Dalam perhitungan ini menunjukkan ada pengaruh signifikan dari nilai pretest posttest menggunakan model student facilitator and explaining terhadap kemampuan berpikir kritis pada siswa kelas V SDN Lamper Tengah 01 Semarang.

Data yang diperoleh digunakan untuk mengukur adanya peningkatan pada kemampuan berpikir kritis siswa kelas V SDN Lamper Tengah 01 Semarang pada tema 7, subtema 2 yaitu Peristiwa Kebangsaan 
Seputar Proklamasi Kemerdekaan. Data tersebut diperoleh dari pretest yang dilaksanakan sebelum siswa memperoleh perlakuan dan posttest yang dilaksanakan setelah siswa memperoleh perlakuan. Berdasarkan data hasil N-Gain menunjukkan dari jumlah 30 siswa, 21 siswa berkriteria sedang, 4 siswa berkriteria tinggi serta 5 siswa berkriteria rendah. Disimpulkan bahwa perbedaan hasil belajar pada siswa kelas V SDN Lamper Tengah 01 Semarang rata-rata berada pada kriteria sedang. Berdasarkan tabel dapat dilihat banyaknya siswa yang tidak tuntas saat pretest ada 6 siswa dengan persentase $20 \%$ dan banyaknya siswa yang tuntas saat posttest ada 26 siswa dengan persentase $87 \%$.

Hasil penelitian diatas menunjukkan adanya perbedaan antara rata-rata nilai pretest-posttest siswa. Untuk nilai rata-rata tes sebelum diberikan perlakuan dengan penggunaan model pembelajaran student facilitator and explaining adalah 65,6 dengan 6 siswa dinyatakan tuntas dan 24 siswa dinyatakan belum tuntas. Setelah diberikan perlakuan dengan menggunakan model pembelajaran student facilitator and explaining nilai rata-rata tes siswa menjadi 81,8 dengan 26 siswa dinyatakan tuntas serta 4 siswa dinyatakan belum tuntas. Hasil perhitungan uji t kemampuan berpikir kritis diperoleh $t_{\text {hitung }}=10,345$ $\mathrm{db}=\mathrm{N}-1=30-1=29$ dengan taraf signifikan $5 \%$ sebesar 2,045 karena $\mathrm{t}_{\text {hitung }}>\mathrm{t}_{\text {tabel }}(10,345>2,045)$ maka $\mathrm{H}_{0}$ ditolak, jadi disimpulkan terdapat perbedaan signifikan antara pretest-posttest dengan menggunakan model pembelajaran student facilitator and explaining terhadap kemampuan berpikir kritis pada siswa kelas V SDN Lamper Tengah 01 Semarang. Hal ini diperkuat dengan uji N-Gain yang berguna untuk mengukur adanya peningkatan kemampuan berpikir kritis siswa yang diperoleh dari pretest-posttest dengan hasil gain 0,4722 (kriteria sedang).

Berpikir kritis adalah suatu kegiatan berpikir tentang gagasan yang berhubungan dengan konsep atau masalah yang dipaparkan Susanto (2013). Berpikir kritis memiliki peran dalam pembelajaran. Semakin tinggi kemampuan siswa dalam berpikir kritis maka semakin mudah bagi siswa untuk dapat mengikuti proses pembelajaran dengan sangat baik. Berdasarkan data hasil penelitian selama tiga kali pembelajaran di kelas V SDN Lamper Tengah 01 Semarang, model pembelajaran Student Facilitator And Explaining memiliki pengaruh terhadap kemampuan berpikir kritis dengan indikator antara lain (1) memberikan penjelasan dasar; (2) membangun keterampilan dasar: (3) memberikan penjelasan lebih lanjut; (4) mengatur strategi dan taktik; (5) membuat kesimpulan.

Meningkatnya rata-rata nilai kemampuan berpikir kritis siswa dikarenakan saat proses belajar mengajar siswa ikut berpartisipasi dan lebih memperhatikan saat pembelajaran berlangsung, dimana pada proses pembelajaran menggunakan model student facilitator and explaining.

Menurut Huda (2017) mengemukakan bahwa Model Student Facilitator And Explaining yaitu proses belajar mengajar yang diawali dengan menjelaskan secara umum, memberikan kesempatan siswa menjelaskan kembali tentang materi yang telah didapat kepada teman-temannya, dan terakhir guru menyampaikan semua materi dari awal sampai akhir kepada siswa. Model Student Facilitator and Explaining adalah model yang melibatkan siswa aktif dalam proses belajar mengajar pada pelajaran tematik kelas $\mathrm{V}$, pada saat proses pembelajaran guru harus memberikan suasana menyenangkan agar siswa tertari dan lebih aktif pada saat proses pembelajaran. Pembelajaran ini efektif melatih siswa untuk bercerita kepada sesama temannya, menyampaikan ide, gagasan atau pendapatnya sendiri. Teknik ini dapat memberikan memotivasi siswa untuk lebih aktif dalam proses pembelajaran dan mendapatkan kesempatan untuk mengajarkan materi yang dia ketahui kepada teman sebayanya, dan dapat melakukakan pemecahan masalah pada diri sendiri.

Penelitian ini didukung oleh Lestari,dkk., (2014) Menyatakan model pembelajaran SFAE adalah model yang melibatkan siswa aktif dalam proses pembelajaran IPA serta memberikan siswa kesempatan untuk menyatakan pendapatnya. Model pembelajaran student facilitator and explaining memanfaatkan dasar-dasar pengetahuan siswa dan kejadian yang sering ditemui dalam kehidupan sehari-hari yang berkaitan dengan konsep yang dibahas yaitu mengenai materi alat pernapasan manusia. Dalam penelitian tersebut menunjukkan adanya pengaruh model pembelajaran student facilitator and explaining terhadap hasil belajar IPA.

Penelitian lain dari Luh Rianti dan Lukman Nulhakim (2017) Hasil analisis data penelitian memperoleh perlakuan model Student Facilitator And Explaining pada pelajaran IPA menunjukkan ada pengaruh signifikan terhadap pemahaman konsep siswa dari nilai postest 61,02 meningkat menjadi 67,28. Dapat disimpulkan siswa yang ada pada kelas eksperimen saat digunakan Model Student Facilitator And Explaining (SFAE) mendapat hasil yang lebih baik dibandingkan dengan siswa kelas kontrol yang menggunakan metode konvesional.

Selanjutnya Hasil penelitian Dewi, E. K. \& Winata, (2018) menunjukkan ada perbedaan kemampuan berpikir kritis yang signifikan saat digunakannya model Student Facilitator and Explaining di dua kelas, yaitu kelas eksperimen atau kelas kontrol dengan hasil uji hipotesis ( $\mathrm{t}_{\text {hitung }}>\mathrm{t}_{\text {tabel }}$ ) menunjukkan ada perbedaan kemampuan berpikir kritis yang sangat signifikan sebelum diberikan perlakuan dan sesudah ada perlakukan dengan model pembelajaran Student Facilitator and Explaining. 
Dari hasil penelitian diatas menunjukkan adanya pengaruh model Student Facilitator and Explaining terhadap kemampuan berpikir kritis siswa kelas V SDN Lamper Tengah 01 Semarang salah satunya ada keterkaitan dan dipengaruhi oleh teori belajar. Faktor teori belajar sangat berpengaruh terhadap bagaimana siswa belajar. Beberapa teori belajar yang berhubungan dengan penelitian ini adalah Teori belajar Piaget dan Teori Jerome Brunner. Menurut Piaget dalam Dimyati dan Mudjiono (2013) bahwa pengetahuan dibentuk dari individu itu sendiri. Perkembangan intelektual ini melalui tahap sebagai berikut. (i) sensori motor (0;0-2;0 tahun), (ii) pra-operasional (2;0-7;0 tahun), (iii) operasional konkret (7;0-11;0 tahun), dan (iv) operasi formal (11;0-keatas). Pada saat tahap operasional konkret anak dapat mengembangkan pikiran yang logis, dan dapat mengikuti penalaran yang logis, walaupun terkadang memcahkan masalah secara "trial and error". Pada saat tahap operasi formal, anak dapat berpikir abstrak seperti pada umumnya orang dewasa. Aplikasi teori Piaget dalam pembelajaran kelas V tentang materi peristiwa dalam kehidupan yaitu peneliti menggunakan media vidio dan benda konkrit, dimana siswa belajar tidak hanya dengan materi yang dijelaskan secara abstrak melainkan ada sebuah gambaran atau benda konkret dari materi yang dipaparkan, sehingga siswa dapat lebih memahami materi ajar tersebut agar siswa tertarik serta aktif pada saat proses pembelajaran berlangsung.

Sedangkan menurut Teori Brunner dalam Slameto, (2013) menyatakan bahwa pada saat proses belajar, keikutsertaan dari siswa sangat aktif untuk mengenal dengan baik adanya perbedaan kemampuan sangat diperlukan. Tiga tahapan belajar menurut Brunner yaitu; (a) tahap enactive, tahap ini siswa menggunakan atau memanipulasi obyek secara langsung dalam pembelajaran; (b) tahap iconic tahap ini kegiatan siswa mulai menyangkut mental yang merupakan gambaran dari obyek-obyek, melainkan mampu memanipulasi dengan menggunakan gambaran dari obyek. Pengetahuan disajikan dari sekumpulan gambar yang mewakilkan suatu konsep; (c) tahap simbolic, tahap ini anak memanipulasi simbol secara langsung dan tidak berkaitan lagi dengan obyek-obyek. Anak mempunyai simbolik berdasarkan sistem berpikir abtrak dan fleksibel. Dalam penyajian pengetahuan akan dihubungkan dari berbagai informasi yang dapat disimpan dalam pikiran dan diproses untuk mencapai pemahaman.

Dalam Teori perkembangan kognitif piaget dan Teori Brunner bahwa interaksi sosial antara teman sebaya, saat berargumen serta berdiskusi dapat membantu memperjelas pemikiran yang akhirnya pemikiran itu menjadi lebih logis. Hal ini sesuai dengan proses pembelajaran Student Facilitator And Explaining yang belajar di dalam kelompok. Pengelompokan pada siswa yang sama mendorong interaksi yang baik yang akan saling mendukung bagi tumbuh kembang agar siswa dapat belajar melalui partisipasi secara aktif dengan konsep dan prinsip, agar mereka mendapatkan pengalaman, dan melakukan percobaan yang mengizinkan mereka untuk menemukan sendiri yang sesuai dengan model Student Facilitator And Explaining mendorong siswa berpartisipasi aktif pada saat proses belajar dan dapat memberikan kesempatan pada siswa untuk saling berbagi informasi, berinteraksi serta belajar bersamasama siswa sehingga pembelajaran akan menyenangkan dan lebih bermakna.

\section{Simpulan dan Saran}

Hasil penelitian dan pembahasan diatas, dapat diambil kesimpulan bahwa ada pengaruh model pembelajaran student facilitator and explaining terhadap kemampuan berpikir kritis pada siswa kelas $\mathrm{V}$ SDN Lamper Tengah 01 Semarang. Kriteria pengaruh tersebut adalah: dari hasil uji t menunjukkan bahwa $t_{\text {hitung }}>t_{\text {tabel }}(10,345>2,045)$ maka Ho ditolak sehingga disimpulkan terdapat perbedaan signifikan antara pre-test dan post-test dengan menggunakan model pembelajaran student facilitator and explaining terhadap kemampuan berpikir kritis pada siswa kelas V SDN Lamper Tengah 01 Semarang. Kemampuan berpikir kritis siswa memenuhi ketuntasan secara klasikal yaitu, terdapat peningkatan hasil belajar siswa dengan hasil skor gain 0,4722 (kriteria sedang).

Berdasarkan hasil penelitian diatas, agar proses dalam pembelajaran dapat memberikan hasil maksimal, penulis perlu menyampaikan saran sebagai berikut: model pembelajaran student facilitator and explaining dapat dikembangkan pada mata pelajaran lainnya agar siswa tertarik dan aktif dalam pembelajaran.

\section{Daftar Rujukan}

Dewi, E. K. \& Winata, H. (2018). Analisis Penerapan Model Pembelajaran Kooperatif Tipe Student Facilitator and Explaining dalam Meningkatkan Kemampuan Berpikir Peserta Didik. Jurnal Pendidikan Manajemen Perkantoran, 2(1).

Eva, M. (2016). Pengaruh penggunaan model pembelajaran kooperatif tipe student facilitator and explaining terhadap pemahaman matematik peserta didik. Jurnal Penelitian Pendidikan Dan Pengajaran Matematika, 2(1), 29-34. 
Huda, M. (2017). Model-Model Pengajaran dan Pembelajaran. Yogyakarta: Pustaka Pelajar.

Lestari, I. dkk. (2014). Pengaruh Model Pembelajaran Student Facilitator And Explaining Terhadap Hasil Belajar IPA Kelas V. Jurnal Mimbar PGSD Universitas Pendidikan Ganesha, 2(1).

Shabir, M. (2015). Kedudukan Guru Sebagai Pendidik: (Tugas Dan Tanggung Jawab, Hak Dan Kewajiban, Dan Kompetensi Guru). Jurnal AULADUNA, 2(2), 221-232.

Sinar Grafika. (2011). Sinar Grafika, Redaksi, KUHP dan KUHAP. Jakarta: Sinar Grafika.

Slameto. (2013). Belajar Dan Faktor-Faktor Yang Mempengaruhinya. Jakarta: PT Rienka Cipta.

Sugiyono. (2017). Metode Penelitian Kuantitatif, Kualitatif, dan R\&D. Bandung: Alfabeta.

Suja, S. (2015). Penerapan Student Facilitator And Explaining Dengan Multimediadalam Peningkatan Pembelajaran Ipapada Siswa Kelas Iv Sdn 2 Waluyorejo Tahun Ajaran 2014/2015.

Susanto, A. (2013a). Teori Belajar dan Pembelajaran di Sekolah Dasar. Jakarta: Prenamedia Group.

Susanto, A. (2013b). Teori Belajar dan Pembelajaran di Sekolah Dasar. Jakarta: Kencana Prenamedia Grup.

Trianto. (2010). Model Pembelajaran Inovatif-Progresif Konsep, Landasan, dan Implementasi Pada Kurikulum Tingkat Satuan Pendidikan (KTSP). Jakarta: Kencana.

Undang-Undang No. 20 tahun 2003 Pasal 1 tentang sistem pendidikan nasional. (n.d.).

Undang-Undang RI Nomor 14 Tahun 2005 Tentang Guru dan Dosen. (n.d.).

Widyawati, S. (2016). Eksperimentasi Model Pembelajaran Student Facilitator and Explaining (SFE) Terhadap Hasil Belajar Ditinjau Dari Kecerdasan Linguistik. Jurnal Pendidikan Matematika, 7(2), 267-274. 